\title{
PMS1 Gene Mutation
}

National Cancer Institute

\section{Source}

National Cancer Institute. PMS1 Gene Mutation. NCI Thesaurus. Code C128822.

A change in the nucleotide sequence of the PMS1 gene. 